\title{
Effects of Exploitation Pressures and River Damming on the Population Structure of Elephant Snout Fish (Mormyrus Kannume) Forsskal 1775: A Case Study on the Upper Victoria Nile
}

\author{
S. Bassa ${ }^{1, *}$, D. O. Owiti ${ }^{2}$, A.Getabu ${ }^{3}$, H.Nakiyende ${ }^{1}$, J. S. Balirwa ${ }^{1}$, W. Nkalubo ${ }^{1}$, J. V. \\ Natugonza ${ }^{1}$, D. Mbabazi ${ }^{1}$, A. M. Taabu ${ }^{1}$ \\ ${ }^{1}$ National Fisheries Resources Research Institute, Uganda. ${ }^{2}$ Department of Fisheries and Natural Resources, \\ Maseno University. ${ }^{3}$ Kissi University.

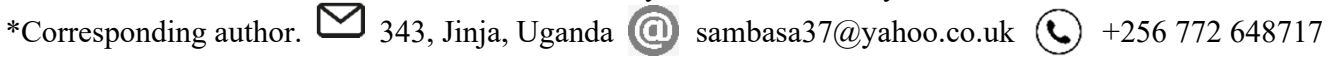

\begin{abstract}
The Elephant snout fish (Mormyrus kannume) Forsskal (1775) is one of the riverine fish species that was previously important for the River Nile riparian people as food and income. The fish is currently exploited mainly as bait for the Nile perch. This study was conducted from 2008 to 2016 and focused on catch rates, value, size structure, maturity status, and feeding habits of M. kannume. Annual catch estimates were made in order to evaluate the exploitation rate of the fish. Results revealed clear fluctuations in catches with a general increase in revenue from 1,200 (000) US\$ to 8,600 (000) US\$. With comparison to available literature, the fish exhibited a smaller size at maturity and smaller mean focal length $\left(\mathrm{L}_{50}\right.$ for males and females were 25.2 and $28.2 \mathrm{~cm}$; mean fork length of $(25.9 \pm 0.32 \mathrm{~cm})$. The observed changes could be due to increased fishing effort along with gear changes from gillnets to basket traps. Therefore the exploitation rate of the Elephant snout fish in the upper Victoria Nile may be unsustainable.
\end{abstract}

Keywords: bait, exploitation, Nile perch.

\section{INTRODUCTION}

Rivers play important roles of providing natural resources such as fish species and clean water. They also provide services such as transportation, energy, diffusion of wastes and recreation. What is not well known, however, is how running waters are structured and function as ecological systems. In this light, man has exploited the natural benefits provided by running waters without understanding how these ecosystems maintain their vitality (Namian and Bilby1998). Examples of such ecosystems include the upper Victoria Nile, which resides in East Africa. This river is part of River Nile which is $6,800 \mathrm{~km}$ long, making it the second longest river in the world after River Missisipi (Dumont 2010). The Nile River is thought to originate from River Ruvyironza a tributary of the Kagera River in Burundi (Dumont 2010, Beadle 1974) with a $2.9 \times 10^{6}$ square kilometre basin. The Nile offers a pathway for African aquatic species to extend distribution from the tropics to a Mediterranean climate and to spill over into the Levant and Arabia. (Dumont 2010).

In addition to that rivers are critical refuge for subset of lake fish species more especially lakes Victoria and Kyoga. The upper Victoria Nile with its critical habitats and wetlands play a big role in the fisheries 
biodiversity whose stocks are also observed in both lakes (NaFIRRI, 2007, Asio et al. 2014). Those reported in open Lake Kyoga were Clarias gariepinus, Protopterus aethiopicus, Oreochromis leucostictus, Mormyrus kannume and Tilapia species (Asio et al. 2014). Barriers tend to maintain fish species in different parts of the riverine wetlands. One of the critical aspects on the wetland disturbance is the dam construction. Dam construction changes both the discharge regime and sediment supply of downstream channels, resulting in channel incision, constriction or widening, and changes in channel substrate (Naiman et al. 1998). Changes in the river ecosystem in addition to wetland disturbances coupled with human fishing effort could deter the fisheries biodiversity. On the upper Victoria Nile, Mormyrus kannume one of the indigenous and dominant fishes, greatly distributed up to Egyptian waters (Okedi 1964); is intensively exploited both as bait and food for the riparian people that need attention.

Fishing has traditionally been an important socio-economic activity of communities riparian to the upper Victoria Nile system since the ancient days. Developmental projects such as dam construction for hydropower production have been implemented on the upper Victoria Nile, raising environmental concerns particularly where appropriate mitigation measures of the negative impacts have not been well captured at the planning level. Fish are sensitive to habitat alterations, and only species tolerant to stressed environments will survive in such altered habitats. River damming is a process so intense and dramatic that it results in the creation of a new ecosystem with a particularly structure, biota and functioning (Agostinho et al.; 2008; Baxter, 1977). The effects of dam construction on downstream areas particularly on the biological and human sub-systems have been described and documented by many authors (e.g. Saha and Barrow, 1981).
Scudder (1980) also documented how the biological and socio-economic productivity of flood-plains have been adversely affected by dam barrage schemes. Some of the potentially negative impacts on the upper Victoria Nile river ecosystem include: alteration of river water flows, increased sediment and nutrient loads and altered biotic communities. Modifications in the ecological and functioning processes of the river system have always resulted into loss of aquatic biota including fish.

Besides nutrient load and alteration of biotic communities due to ecological modification, the resource that is utilised by the fishers as source of income and food, have been affected negatively. This effect was depicted in the upper Victoria Nile with low catches of the Elephant snout fish. The Elephant snout fish which was historically a preserve for the men (Okedi 1964) is now consumed by all sexes and plays a big role in food security. Besides that intensive exploitation using basket traps on the Nile River for bait is rampant. The effect of the dam and the level of exploitation is not known. Therefore, this study is aimed at addressing the population characteristics, fishing effort, fishery yield and economic value of the $M$. kannume in the upper Victoria Nile. This is in order to guide the fisheries management in the conservation and sustainable use of the fishery.

\section{MATERIALS AND METHODS}

\section{Study Area and Sampling Sites}

The study was undertaken in the upper Victoria Nile from the Source of the Nile towards Lake Kyoga (Figure 1) from 2008 to 2016. This part of the River Nile has several tributary streams such as the Bugungu, Naava and Kalagala. The river passes through Lake Kyoga and flows into Lake Albert, up to the Mediterranean Sea. 


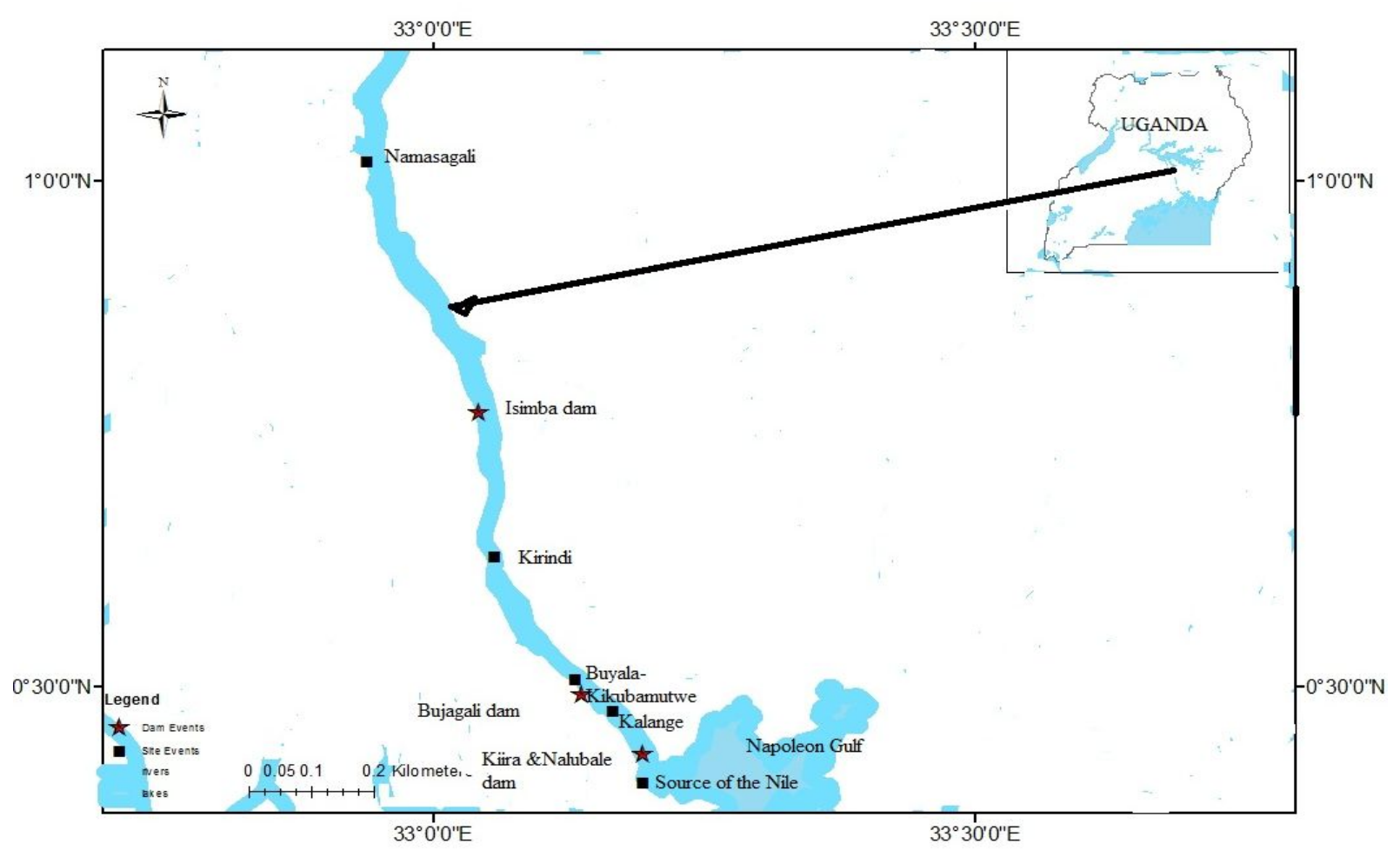

Figure 1: Sampling sites. 
Five transects (Sites) were identified for the study based on the following criteria: - 1) accessibility on either side of the bank of the river 2) status of the fishing activities at the selected site. 3) proximity upstream or downstream of the site to hydro-electric power sites 4) transects that covered a wide range of habitats 5) ease of sampling aspects of study objectives; 6) sites considered to be representative of the upper Victoria Nile as a whole. The sites were; The Source of the Nile whose location is $00.40456 \mathrm{oN}, 33.19337 \mathrm{oE}$. It is above the Owen falls dam, the railway line and both the old and new constructed bridges. The aquatic plants in this site are papyrus, water hyacinth, Ambaci trees and ferns. It has both lentic and lotic characteristics.

Then Kalange-Kikubamutwe which is located $00.4748 \mathrm{oN}, 33.16634 \mathrm{oE}$ it is $6 \mathrm{~km}$ upstream of the Bujagali hydro power station located on formerly Dumbel Island. This transect lies downstream of the Kiira/Owen falls dam. Five islands occur in the transect. The east bank is more gently sloping towards the river and more extensively cultivated than the western bank. Along the river margins Vossia cuspidate is the dominant macrophytes occurring in 5 to $15 \mathrm{~m}$ wide strips. The tree cover on islands was composed of Tremor orientalis and Ficus species. Kikonko, Kunjaba, Makwanzi Island are some of the associated villages associated with this site. The Buyala site is located downstream of the Bujjagali dam whose position $00.50733 \mathrm{oN}, \quad 33.13124 \mathrm{oE}$ just one kilometre from the dam. This zone is characterised by steep banks on both sides of the river channel. There are rocky reaches and the shoreline for the most part was free of stable vegetation cover. The site was chosen because of its characteristic steep banks on both sides of the river. Some of the Aquatic plants (Phragmites australis and Vossia species and little Water hyacinth (Eichhornia crassipes) were present. Below this site are very first moving waters with a lot of rocks. The Kirindi site $0.68271 \mathrm{oN}, 33.056261 \mathrm{oE}$, is 24 $\mathrm{km}$ downstream of the Bujagali dam. The site was approached from the more gently sloping west bank at Kirindi. The river channel here is interrupted by a series of islands in an otherwise fast current. At the river margins, the main plant communities associated with this site are Vossia cuspidate and Phragmites mauritianus. Beyond the river margins, the land on both sides of the channel is extensively cultivated.

The transect was selected because is intensively cultivated near the banks. The Namasagali site located at $01.01828 \mathrm{oN}$, $32.93835 \mathrm{oE}$, the site is $65 \mathrm{~km}$ downstream of the Bujagali dam. This is the most down-stream site if the survey area and is located at Namasagali. In comparison to the upstream sites, the river channel here is wider about $1.5 \mathrm{~km}$ and characterised by a more gentle flow. The channel is also associated with a narrow but more defined flood plain and its margins. Both banks are fringed by extensive Cyperus papyrus swamp. The river shoreline has frequent patches of Eichhornia crassipes and other floating water plants.

\section{Catch Assessment, Frame and Fish Biology Survey Design}

The landing sites formed the primary sampling units (PSUs) while the vessel-gear (VG), categories at each landing site formed the secondary sampling units (SSUs). At each landing site only fishing boats with fishing gears were selected for sampling. A random sample of active fishing boats was selected for each of the gear type in use encountered at the landing site. Information recorded for each sampled boat included the sampling date type of boat, number of days the boat fished in the last one week, time of fishing (day or night), mode of propulsion of boat (paddle or motor), number of crew, gear type, gear number and size, number and 
weight of the fish species targeted. were recorded in centimetres.

Individual lengths of the targeted species

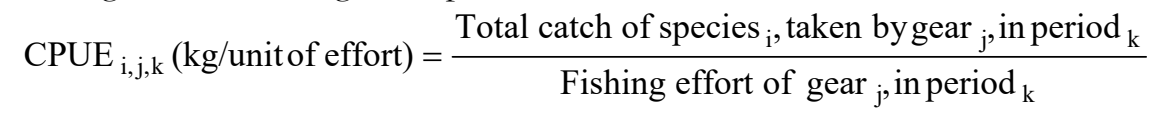

The price per kilogramme weight of the fish landed was also recorded. Information from Frame and Catch Assessment Surveys was used to determine the yield over time of the exploited fishery.

The biology of M. kannume was investigated as follows: three fleets of gillnets of mesh size one (1) inch (25.4mm) to eight (8) inches (203 $\mathrm{mm}$ ) mesh sizes in increments of $1 / 2$ inch up 5.5" then 6, 7 and 8". The gillnet sets were sampled twice per site following the Standard operating procedures (SOPs) for biological studies (LVFO 2007). Fish samples from the gillnets were sorted by species and mesh size. Individual weights per fish specimen were taken in kilogram weight. Then individual fork and standard lengths in centimetres were recorded. Each fish was dissected in order to determine the sex and also the type of food in the stomachs. Stomach contents that could not be identified in the field were preserved in $4 \%$ formalin solution for laboratory analysis. Stomach analysis followed the point methods designed by Hynes 1960s and modified as in (Natarajan and Jhingran 2011, Mbabazi et al. 2014). Sex ratio was analysed by determining the number of males to females of the M. kannume. The results from sex ratio are useful to determine the proportion of mature males to mature female in the fish population, reproductive capacity, breeding areas and seasons. Chi-square test was done on the sex ratios. Coding of maturity stages used the Sops developed by Hopson (1972) and adopted by the HEST/TAFIRRI for Nile perch on Lake Victoria (Ligvoet, et al. 1995).

Length at $50 \%$ maturity growth parameter was used to estimate the maturity ogive for females and males of $\mathrm{M}$.
Kannume. The length weight relationship data of commercial fishes was calculated by the power function equation. $\mathrm{W}=\mathrm{aLb}$ where "W" is the total weight $(\mathrm{g})$, " $\mathrm{L}$ " is the total length $(\mathrm{cm})$, " $\mathrm{a}$ " is the intercept and " $b$ " is the slope.

Both the FISAT tool and the Elefan program were applied to estimate growth parameters; recruitment, estimating the catch curves and cohort analysis. Asymptotic length $(\mathrm{L} \infty)$ and growth coefficient $(K)$ of the von Bertalanffy equation for growth in length were estimated by means of ELEFAN (Pauly and David, 1981, Gheshalghi et al 2011). The to value estimated using the empirical equation $\log 10 \quad$ (-to) $=-0.3922$ $0.2752 \log 10 \mathrm{~L} \infty-1.038 \log 10 \mathrm{~K}$ (Sparre and Venema 1998).

The growth performance of the important commercial fisheries population in terms of length was compared as: $\theta=\log 10 \mathrm{k}+2 \log 10 \mathrm{~L} \infty$ (Sparre and Venema 1998). Maximum age (tmax) was estimated as $\operatorname{tmax}=3 / \mathrm{k}+$ to (Sparre and Venema 1998).

The Natural mortality (M) was estimated by Pauly empirical formula where by $\ln \mathrm{M}$ $=(0.0152-0.279 * \ln \mathrm{L} \infty+0.6543 * \ln \mathrm{K}$. $\left.+0.463^{*} \ln \mathrm{T}\right)$. Where $\mathrm{L} \infty$ is the length at infinity, $\mathrm{K}$ is growth $\theta$ constant and $\mathrm{T}$ is the mean temperature of the water body. Fishing mortality (F) was obtained by subtracting $\mathrm{M}$ and $\mathrm{Z}$ and exploitation rate (E) was estimated from F/Z. Total mortality ( $Z$ ) was estimated using length converted catch curve method as implemented in ELEFAN II. The Condition factor or condition coefficient of conditions $(K)$ was calculated by the cube law: $K=100 W / L 3$ (Ragheb 2016) where $\mathrm{W}$ is the weight in grams and $\mathrm{L}$ is the total length of the fish in $\mathrm{cm}$. 


\section{RESULTS}

\section{Relative Indices and Economic Evaluation}

Catch rates of $6.7 \pm 2.5 \mathrm{~kg} / \mathrm{boat} /$ day were recorded during 2008 for all fishing gears in all sites and these gears comprised gillnets hook and line, long line and cast nets. In 2012 catch rates of $1.94 \pm 0.49 \mathrm{~kg} /$ boat per day were recorded during that period for all gears meanwhile the basket traps catch rates of $1.6 \pm 1.40 \mathrm{~kg} / \mathrm{boat} / \mathrm{day}$ were observed. Between 2012 and 2016 there was a three-fold (c.443\%) increase of the fish catch harvested by basket traps (Table 1).

The average price rose from $0.41 \pm 0.00$ US $\$$ in 2012 to $2.43 \pm 0.21$ US $\$$ per $\mathrm{kg}$ in 2016 for the fishes harvested by basket traps as compared to those from other gears with $0.34 \pm 0.03$ to $0.77 \pm 0.10$ US $\$$ per $\mathrm{kg} / \mathrm{boat} /$ day in the respective years in the upper Victoria Nile (Table 1). ANOVA test for differences in means per boat per day indicated a significant difference $(\mathrm{P}<0.05)$.

Table 1. Catch rates and value of the M. kannume from various fishing gears sampled

\begin{tabular}{lcccc}
\hline \multirow{2}{*}{ Year } & \multicolumn{2}{c}{$\begin{array}{c}\text { Gillnet, Hook and line, Long line and Cast net } \\
\text { Av.wt(kg) }\end{array}$} & \multicolumn{2}{c}{ Basket traps } \\
& $6.69 \pm 2.52$ & $0.61 \pm 0.04$ & & \\
\hline 2008 & $4.39 \pm 1.38$ & $0.49 \pm 0.03$ & & \\
2009 & $4.05 \pm 0.81$ & $0.62 \pm 0.02$ & & \\
2010 & $1.94 \pm 0.49$ & $0.34 \pm 0.01$ & $1.6 \pm 1.40$ & $0.41 \pm 0.00$ \\
2011 & $3.85 \pm 1.55$ & $0.46 \pm 0.03$ & $3.0 \pm 0.37$ & $1.02 \pm 0.00$ \\
2012 & $2.57 \pm 0.56$ & $0.77 \pm 0.14$ & $5.1 \pm 1.22$ & $2.79 \pm 0.00$ \\
2013 & $1.79 \pm 0.50$ & $0.42 \pm 0.03$ & $3.2 \pm 0.61$ & $1.84 \pm 0.34$ \\
2014 & $1.15 \pm 0.35$ & $0.90 \pm 0.12$ & $2.4 \pm 1.28$ & $0.93 \pm 0.16$ \\
2015 & $1.88 \pm 0.40$ & $0.77 \pm 0.10$ & $7.1 \pm 1.28$ & $2.43 \pm 0.21$ \\
2016 & $3.21 \pm 0.40$ & $0.48 \pm 0.03$ & $5.0 \pm 0.65$ & $1.83 \pm 0.13$ \\
Grand Total & & & & \\
\hline
\end{tabular}

Table 2. Catch rates of M. kannume in the upper Victoria Nile.

Monitoring period

Transect

$\begin{array}{llllllll}2009 & 2010 & 2011 & 2012 & 2013 & 2014 & 2015 & 2016\end{array}$ Apr. Oct. Apr. Sep Apr. Sep Apr Sep Apr Sep Apr Sep Apr Sep Apr

\begin{tabular}{lllllllllllllll}
\hline Upper Stream 2.93 & 0.43 & 1.84 & 2.03 & 0.25 & 0.7 & 5.47 & 1.5 & 1.35 & 1.4 & 0.7 & 2.3 & 2.2 & 1.1 & 2.1
\end{tabular}

$\begin{array}{lllllllllllllllll}\text { Reservoir } & - & - & - & - & - & - & 1 & 4.7 & 0.96 & 3.4 & 3.3 & 4.8 & 0.4 & 2.7 & 2.7\end{array}$

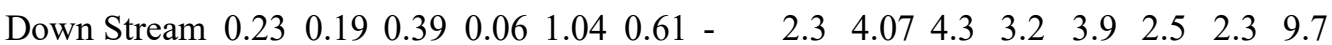

The mean catch rate of in each transects indicated $2.93 \mathrm{~kg} / \mathrm{boat} /$ day in 2009 and fluctuated to $2.4 \mathrm{~kg} /$ boat/day in 2016 as compared to the downstream i.e. below the Bujagali dam with $0.23 \mathrm{~kg} / \mathrm{boat} /$ day to $9.7 \mathrm{~kg}$. boat $/$ day in the respective years (Table 2). The annual production indicated 5 tonnes to 28 tonnes in years of 2008 to 2016 with corresponding increase in value from 1,200 (000) US\$ to 8,600 (000) US\$ in the same period (Figure 2). From the experimental gillnets the CPUE ranged from $0.17 \pm 0.02$ to $0.20 \pm 0.03$ net/day in 2008 and 2016 respectively (Figure 4). ANOVA test on the catch rates (CPUE) from the experimental data for the period sampled and indicated $(\mathrm{F}=3.84698$ : $\mathrm{p}<0.05)$. 


\section{Population Characteristics and Size Structure}

The size structure and population characteristics indicated the fish harvested were below the $50 \%$ maturity as observed in the length frequency information from experimental data with $\mathrm{L}_{50}$ for males and females were 25.2 and $28.2 \mathrm{~cm}$ fork length respectively. The fish harvested during the sampling ranged from $9.0-69.0 \mathrm{~cm}$ fork length in the early years of $2008,95 \%$ of the fish caught was above $\mathrm{L}_{50}$; then later as we moved on $73 \%$ were observed to below the maturity ogive up to April 2016. Basing on the length Catch converted curve method; the Total mortality (Z) was estimated to $0.61 \pm 0.28$ (Figures 3, 4, 7). The instantaneous rate of growth rate $\mathrm{K}$ and asymptotic length at infinity $\left(\mathrm{L}_{\infty}\right)$ were estimated at $\mathrm{K}=0.14$ and $\mathrm{L}_{\infty}=73.50 \mathrm{~cm}$. The length weight relationship indicated $\mathrm{b}=3.0$ and $\mathrm{a}=0.0001$ with $\mathrm{R}^{2}=0.9375$. Using mean water temperature Nile at $26.95^{\circ} \mathrm{C}$ the Pauly empirical formula estimated the Natural mortality (M) at 0.377 and $\mathrm{M} / \mathrm{K}$ was 2.525 (Figure 5, Tables 3 and 4).
The yield per recruit analysis (knife-edge selection Isopleth) method the exploitation rate was estimated at 0.421 (Figure 6). With the application of the length-structured virtual population analysis (VPA) the fishing mortality (F) was 0.259. The Sex ratio of this fish ranged from 0.5:0.4 for males to females in almost throughout the whole period of sampling. Chi-square test on the sex ratios indicated $\left(\mathrm{X}^{2}=227.573\right.$; $\mathrm{df}=1 \mathrm{P}<0.05)$. 


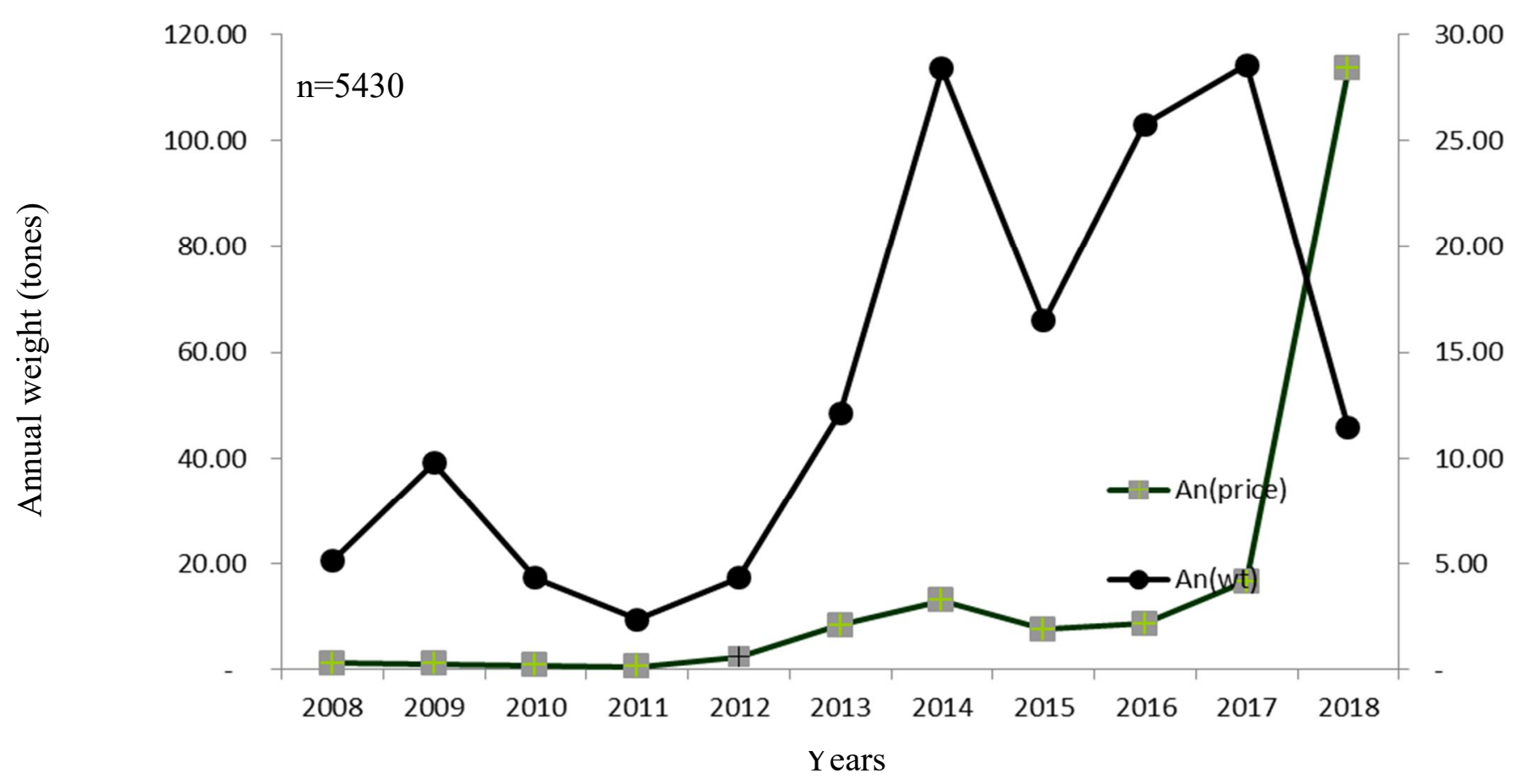

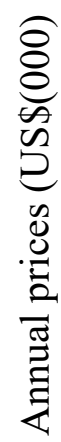

Figure 2. Annual catch and value of the M. kannume (2008-2018). 
Table 3. Food and feeding of the Mormyrus kannume in the upper Victoria Nile in percentage indices.

\begin{tabular}{llllllllll}
\hline Year & 2008 & 2009 & 2010 & 2011 & 2012 & 2013 & 2014 & 2015 & 2016 \\
\hline Povilla & 28.98 & 39.64 & - & 11.71 & 19.96 & 21.19 & 10.59 & - & 34.01 \\
Caridina niloticus & - & 39.64 & - & - & 3.15 & 6.67 & 4.76 & 8.69 & 1.72 \\
Chironomids & 19.32 & - & 14.37 & 12.45 & 9.56 & 10.84 & 5.09 & 23.68 & 14.09 \\
Cheobrus larvae & - & 4.95 & - & - & - & - & - & - & - \\
Ephemenotera & - & - & 22.22 & 38.05 & 19.38 & 7.26 & 10.74 & 28.96 & - \\
Odonata & - & - & - & 10.46 & 11.91 & 13.47 & 4.25 & 9.56 & 3.00 \\
Tricoptera & 28.98 & - & 17.90 & 3.21 & - & 3.10 & - & - & - \\
Hemiptera & - & - & - & - & - & - & 0.18 & - & - \\
Mollucus & - & - & 7.41 & 0.83 & - & - & - & 20.42 & - \\
Insect Remain & 22.71 & 15.77 & 10.58 & 16.98 & 5.03 & 11.41 & 3.63 & 8.69 & - \\
Oligochaeta & - & - & 3.70 & 3.09 & 5.29 & - & - & - & - \\
Leech & - & - & - & 3.21 & - & - & - & - & - \\
Crab & - & - & - & - & - & - & 60.72 & - & - \\
Detritus & - & - & 23.81 & - & 18.79 & 3.10 & 0.04 & - & 41.18 \\
Ostracodes & - & - & - & - & 6.92 & - & - & - & 6.00 \\
Green & - & - & - & - & - & 22.96 & - & - & - \\
\hline
\end{tabular}

Table 4. Selected authors' estimated growth parameters and natural mortality for $M$. kannume in different regions of the Nile.

\begin{tabular}{|c|c|c|c|c|c|c|c|c|}
\hline Author & Location & $\mathrm{K}$ & $\mathrm{L}_{\infty}$ & $t_{0}$ & $\mathrm{~W}_{\infty}$ & $\varnothing \mathrm{L}$ & ØW & $\mathrm{M}$ \\
\hline El-Etreby (1985) & Lake Nasser & 0.061 & 156.260 & -1.137 & 24927 & 3.170 & 1.720 & 0.160 \\
\hline Aly (1993) & High Dam reservoir & 0.147 & 96.100 & 0.029 & 8482 & 3.130 & 1.790 & 0.320 \\
\hline Ahmed (2007) & Nile at Assiut & 0.148 & 67.940 & -0.836 & 2683 & 2.830 & 1.520 & 0.350 \\
\hline Khallaf and Authman (2010) & Bahr Shebeen Nilotic Canal & 0.100 & 79.670 & -1.634 & 6050 & 2.800 & 1.520 & 0.270 \\
\hline Evelyn Ragheb (2016) & Damietta branch of Nile Egypt & 0.141 & 80.650 & -0.271 & 4151 & 2.960 & 1.560 & 0.340 \\
\hline S.Bassa et al (2019) & Upper Victoria Nile & 0.140 & 73.500 & -0.026 & 4200 & 2.880 & 2.879 & 0.377 \\
\hline
\end{tabular}


Table 5. Selected authors' estimated length-weight parameters and coefficient of conditions (K) for M. kannume in different regions of the Nile.

\begin{tabular}{llllll}
\hline Author & Location & $\mathrm{a}$ & $\mathrm{b}$ & $\mathrm{R}^{2}$ & Condition factor \\
\hline Forkal length & & & & & \\
Solima (1994) & Nile at Sonhag & 0.0120 & 2.934 & 0.998 & 0.97 \\
Khallaf and Autham (2010) & Bahr Shebeen Nilotic Canal & 0.0070 & 3.033 & 0.998 & 0.78 \\
Evelyn Ragheb (2016) & Nile at Assiut & 0.0060 & 3.063 & 0.997 & \\
S.Bassa et. al (2019) & Upper Victoria Nile & 0.0001 & 3.000 & 0.938 & 1.06 \\
\hline
\end{tabular}




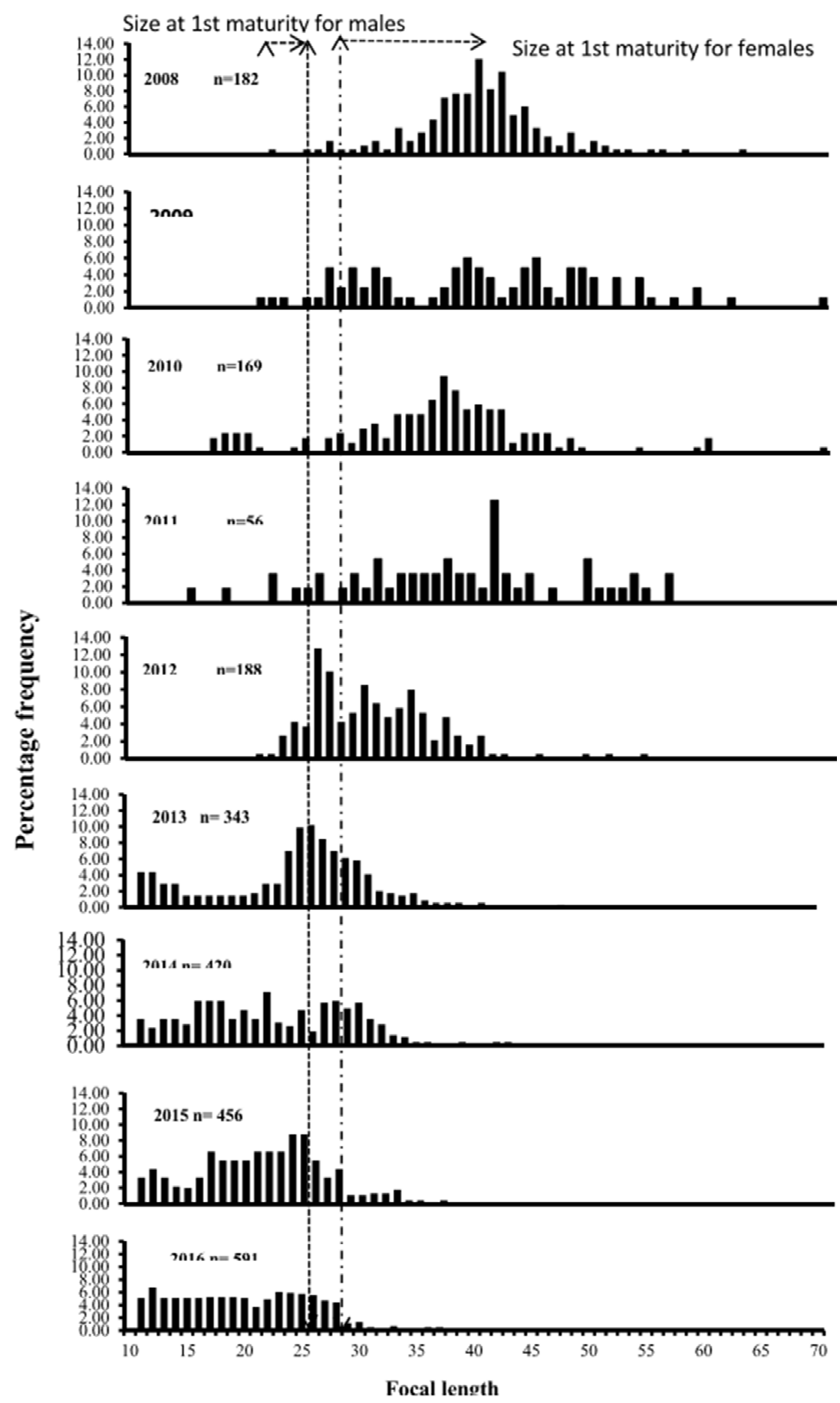

Figure 3. The size structure of M. kannume from the Catch assessment studies (2008 to 2016). 


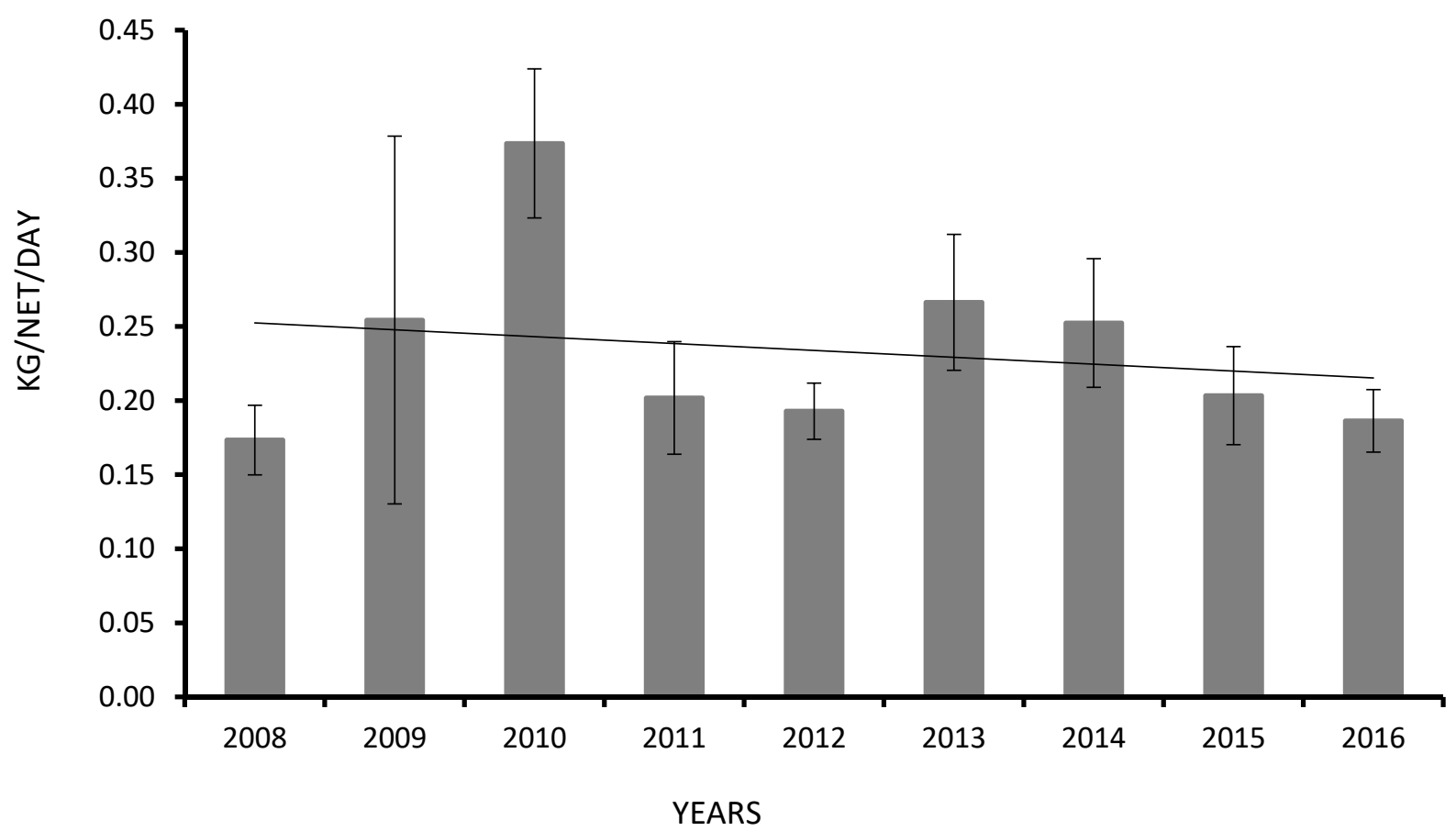

Figure 4. Catch rates of M. kannume from the gillnet experiment studies (kg/net/day) from 2008 to 2016 on the upper Victoria Nile. 


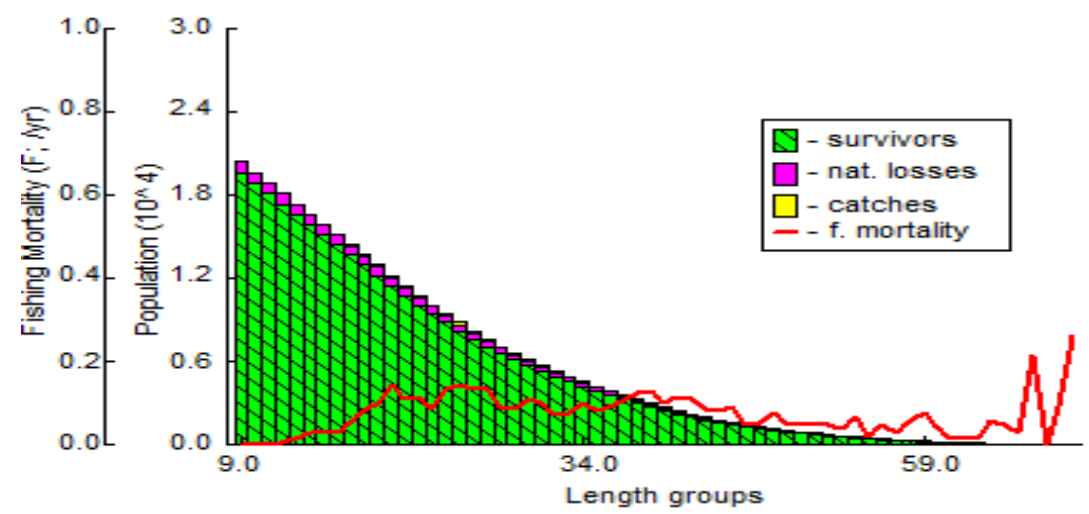

Figure 5. Length-structures Virtual Population analysis (VPA) on the M. kannume indicating the fishing mortality $(\mathrm{F}=0.25)$ sampled from the upper Victoria Nile for the period of 2008 to 2016 from the experimental data.

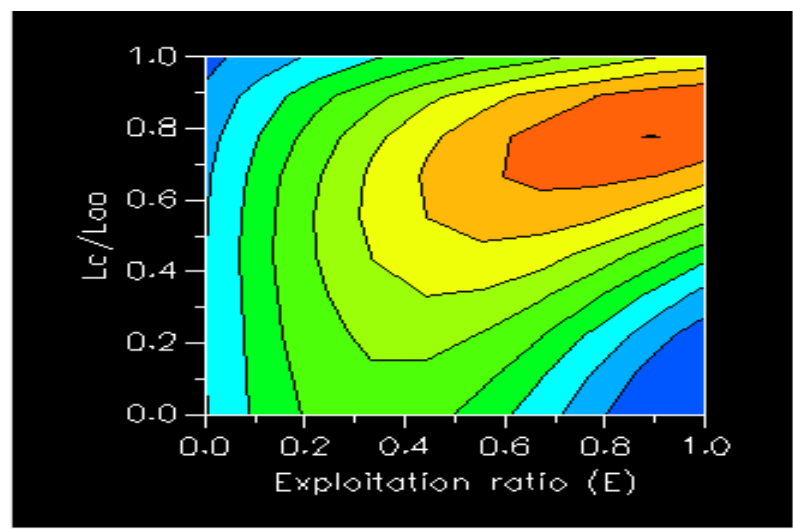

Figure 6. Yield per recruit analysis (knife-edge selection Isopleth) the Exploitation rate $(\mathrm{E}=0.42$ ) of the M. kannume from the experimental data sampled from 2008 to 2016.

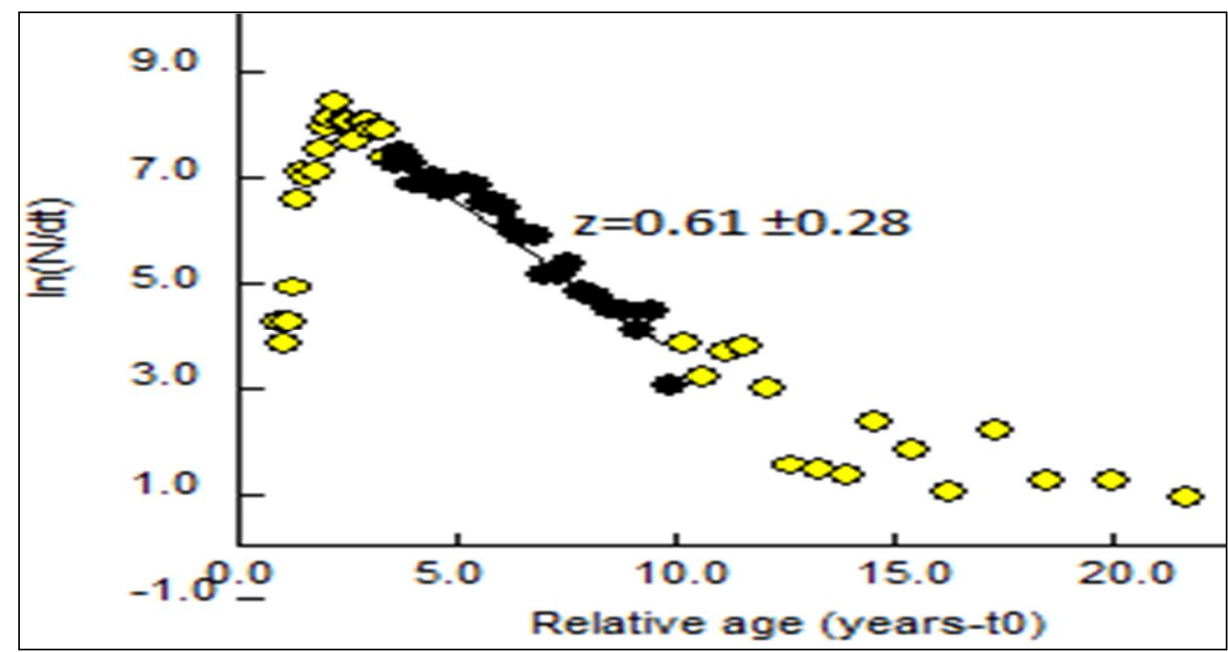

Figure 7. The Total mortality ( $\mathrm{Z}$ ) of the M. kannume from the experimental data sampled from 2008 to 2018 in the upper Victoria Nile. 


\section{Food and Feeding Interactions}

Sixteen (16) food types were identified from the gut contents of the M.kannume species. Some of the types included; Macro invertebrates like Ephemeroptera, Povilla, Caridina niloticus, Chronomids, Cheobrus larvae, Ephemenotera, Odonata, Tricoptera, Hemiptera and the Insect remains; the Mollucus, the leech and the Oligocheta were dominant food types. Fishes ranged 40-48.6 cm fork length the majority depended on Povilla larvae, Trichoptera, Caridina nilotica and Odonata. The fishes that ranged from $50-89 \mathrm{~cm}$ fork length depended on Odonata, Povilla larvae and Chironomids, (Table 3). The Chi-square $\left(X^{2}\right)$ test was used to tests for significance of differences in the diet within and between periods of sampling these were: Povilla larvae $\left(\mathrm{X}^{2}=177.292 ; \mathrm{df}=19\right.$ : $\mathrm{P}<0.05)$, Ephemeroptera $\left(\mathrm{X}^{2}=23.00 ; \mathrm{df}=9\right.$ : $\mathrm{P}<0.05)$, Trichoptera $\left(\mathrm{X}^{2}=36.250 ; \mathrm{df}=11\right.$ : $\mathrm{P}<0.05)$, Insect remains $\left(\mathrm{X}^{2}=59.261 ; \mathrm{df}=5\right.$ : $\mathrm{P}<0.05)$ and Chironomid larvae $\left(\mathrm{X}^{2}=216.983\right.$; $\mathrm{df}=19: \mathrm{P}<0.05)$.

\section{DISCUSSION}

Fluctuations in mean catch rates from 2008 to 2016 with increasing annual beach revenue of 1,200 US $\$$ to $8,600(000)$ US $\$$ is an indication of how the M.kannume has gained value due high exploitation by man as bait for the Nile perch fishing on Lake Victoria. The exploitation is supported by information of the open access nature of the small scale fisheries, widely scattered by nature that has been led by fishing communities and landing sites making it difficult to regulate fishing and related activities (Asio et al. 2014, Bassa et al 2014). The significant variation indicates to the extent how this fishery has been exploited in the upper Victoria Nile both as bait and food by the riparian people along the shores of the river. Besides that this could be attributed by the exploitation of the fishery by use of basket traps moving away from the traditional gillnet setting on the Nile River. Change in the fishery is also due to the change in the utilisation of the Elephant snout fish as both as food and source of bait for the Nile perch fishing in Lake Victoria. Literature indicate that bait in the Victoria basin has changed the method of fishing in all the system that has led to depletion of the ecosystem (Bassa 2011, Mkumbo and Mlaponi 2007, Chitamebwa et al 2009)

In terms of size structure, the fishery has been observed to mature at smaller size as compared to the literature. These sizes have been decreasing at a temporal basis over time indicate the intensive harvest of the Elephant snout fish in the upper Victoria Nile. A decrease in size has also contributed to maturity at smaller size of 25.2 and $28.2 \mathrm{~cm}$ fork length of males to female resulting the length at infinity $\left(\mathrm{L}_{\infty}\right)$ at $73.50 \mathrm{~cm}$ as compared to $80.65 \mathrm{~cm}$ (Rahgeb 2016) in the river Nile Egypt waters.

The growth parameters indicated a significant difference spatial scale in the upper Victoria Nile. Fluctuations in these parameters was observed in the total mortality $(Z=0.61 \pm 0.28)$ with yield per recruit analysis (knife-edge selection Isopleths) the Exploitation rate of $\mathrm{E}=0.42$, $\mathrm{K}, \mathrm{t}_{\mathrm{o}}, \mathrm{W}_{\infty}, \varnothing \mathrm{L}, \varnothing \mathrm{W}, \mathrm{M}, \mathrm{L} \infty$ and $\mathrm{R}^{2}$ values. This was an indication of the fishery utilisation in the riverine ecosystem that needs attention by the fisheries managers. Information from the Caspian Sea using the growth parameters, mortality rates, yield per recruit, biomass and MSY using length frequency analysis has assisted to advise managers in keeping the fishing to better levels and thus sustainable yield (Gehshlaghi et al 2011) this could also be applied in the upper Victoria Nile.

Besides the growth parameters, sex ration have been identified as an important tool when choosing freshwater fish species for farming (Ragheb 2016). In such a circumstance sex ration must be put into the production consideration more 
especially on resource allocation between female and male production (Iles 1960, Greenwood 1966, Mekkauy and Hassan 2012, Golobstov and Orlov 2013, Ragheb 2016). In the upper Victoria Nile, the ratio varied 0.5:0.4 for males to females as compared in the Nile waters of Egypt, Damietta branch of the Nile with 1:0.8 respectively (Ragheb 2016) an indication of how these fishes are maturing at a smaller size in this ecosystem.

It was observed that the M.kannume mainly fed on the Macro invertebrates like Ephemeroptera, Povilla, Caridina niloticus, Chronomids, Cheobrus larvae, Ephemenotera, Odonata, Tricoptera, Hemiptera and the Insect remains; plus low quantities of the Mollucus, the leech and the Oligocheta. The feeding habits of the fish indicated a significant variation in all sites sampled. Feeding indicates that these fishes are bottom feeders and due to that the organisms identified from the gut contents were from bottom strata of the water system. Modification of the water system and creation of barrages attributes can lead to low density of macro invertebrates in the ecosystem being driven by change in the riverine system as in Vannote et al. (1998) river continuum theory. This is due the Microbial biomass plus modified detritus that serves as food source for detritivores (both invertebrate and vertebrate) that are common in streams and rivers (Keller 1998). This could have led to low catches of the M.kannume in addition of the intensive exploitation by the fishers.

The riverine fishery that falls under the small scale fishery provides poverty prevention contributing to food security, nutrition and employment. Though, this small scale was under -valued besides that was an appreciated with no management program geared to it. Increase in the riverine disturbance, the system will soon fail to fulfil its socio-economic importance thus low level catches leading to the collapse of the fishery. Therefore riverine resource utilisation policy should be developed, drawing its contents from immediate environment and it should be adapted to local conditions, and being aligned with the range of livelihood functions performed by the riverine fishery in the upper Victoria Nile. This will lead to biodiversity conservation and sustainable utilisation of the resource.

\section{ACKNOWLEDGEMENTS}

The study was supported by the data collected for the Bujagali hydro power dam (BEL) by National Fisheries Resources Research Institute I appreciate the support of my colleagues at NaFIRRI, especially, Ms. Nsega Monic, Muhumuza Elias, Kamya Asharaf, Mr.Sande Kirigola Salongo, Mr. Madoi Medi the Coxswains and our beloved one Mr. Musana Isa (RIP) and Mr. Magezi Godfrey who assisted me in the data collection; plus other NaFIRRI staff in the support.

\section{REFERENCES}

Agostinho, A., Pelicice, F., Gomes, L. (2008). Dams and the fish of the Neotropical region: impacts and management related to diversity and fisheries. Brazilian journal of Biology, 68(4), 1119-1132.

Asio A.G, Kipkemboi J., Mathooko M.J., Balirwa J (2014). Land-use impacts on small-

Scale Mpologoma wetland fishery, eastern Uganda: A socio-economic perspective. Lakes and Reservoirs: Research and Management 19:280-292.

Bassa, S. (2011). The effect of hook size on the Catch rate and size of the Nile perch

Lates niloticus (LINNE) fishery in the Napoleon Gulf, Lake Victoria Uganda. (Msc thesis Islamic University, Uganda).

Baxter, R. (1977). Environmental effects of dams and impoundments. Annual Review of Ecology and Systematics, 8, 255-283. 
Beadle J.C. (1974). The Inland waters of Tropical Africa. Introduction to Tropical limnology. The great rivers of Africa 121-137.ISBN 0582 4448522.Library of Congress Catalogue card number 7385680.Printed in Great Britain by Lowe and Brydone (Printers Ltd, Thefford Norfolk.

Chitamwebwa, D., Kamanyi, J., Kayungi, J., Nabbongo, H., Ogolla A., Ojuok, J. (2009).The

Present Status of the Hook Fishery and its Impact on the Fish Stocks of Lake Victoria.

African Journal of Tropical Hydrobiology and Fisheries12: 78-82 (2009) (C) Lake Victoria Fisheries Organization.

Dumont H.J. (2010).Descriptions of the Nile basin. Monographiae Biologicae; The

Nile: Origin, Environments, Limnology and Human Use vol. 89, 1-2.

Greenwood P.H (1966). The fishes of Uganda. Published by The Uganda Society Kampala.

Golobstov, A. S., Orlov, A.A. (2013). Variation of Electric organ discharge in Mormyrus

kannume (Mormyridae) from SouthWestern Ethiopia in relation to individual size, sex and reproduction status. ISSN 0032-9452, Journal of Ichthyology, Vol.54, No.2. pp., 177-185, (a) Pleiades publishing, Ltd.

Hynes, H.B.N. (1950). The food of the freshwater stickle-backs

(Gasterosteusaculeatus and Pygosteuspungitius) with a review of methods used in the studies of the food of fishes. J. Anim. Ecol., 19, 36-58.

Iles, R. B. (1960).External sexual differences and significance in Mormyrus kannume

Forsakal. 1775. Nature vol. 188, No.4749, p516. Printed in Great Britain by Fisher, Knight and Co. Ltd.
Keller F.S. (1998) Microorganism and organic matter decomposition. Naiman R.

Bilbyedseds: The River ecology and management. Lessons from the pacific Coastal Eco- region. Springer publishing Company.

Ligvoet, W., Mkumbo O.C., Mous P.J., Goudswaard P.C., (1995). Monitoring fish stocks

from survey data, Page 119-186; In Witte F. (Eds.) Fish stocks and Fisheries of Lake

Victoria; A hand book for field work observations. Samara Publishing Limited, Wageningen The Netherlands.

LVFO, (2005).Standard Operating Procedures SOPs for Catch Assessment Surveys on Lake

Victoria. LVFO Standard Operating, LVFO, Jinja.

LVFO, (2007a).Standard Operating Procedures SOPs for Collecting Biological information

from the fishes of Lake Victoria. LVFO Standard Operating Procedures No. 1, LVFO, Jinja.

Mbabazi, D., Taabu, M.,A., Nakiyende, H., Balirwa, J.,S., Bassa, S., Muhumuza, E., Nsega,

M., Namulemo, G., Tazibirwa, J., Amiina,. B. (2014). Survey of fish populations in the Victoria Nile/Nile delta, Ramsar site area of Murchison falls National Park (MFNP).

Mekkawy A.A.I. and Hassan, A.A.(2012). Reproductive characteristics of the Elephant snout

Fish Mormyrus kannume Forsskal, 1775 from the Nile. Egypt. Journal of Biology Science 12(1): 15-24

Mkumbo, O.C., and Mlaponi, E. (2007). Impact of the baited hook fishery on the recovery

endemic fish species of Lake Victoria. Aquatic Ecosystem Health and Management, 10,458-466. 
Mwebaza-Ndawula L, Kiggundu and S. Sekiranda (2005). Variability of zooplankton

community along a section of the Upper Victoria Nile, Uganda. https://doi.org/10.1111/j.1365-

2028.2005.00583.x downloaded 27th April 2019.

Naiman J.R and Bilby R.E (1998) River Ecology and Management in the Pacific Coastal

Ecoregion. The River ecology and management. Lessons from the pacific Coastal Ecoregion. Springer publishing Company.

Natarajan, A. and A. Jhingran (2011)."Index of preponderance and method of grading the

food elements in the stomach analysis of fishes." Indian Journal of Fisheries 8 (1): 54-59.

Okedi J. (1964). The biology and habits of Mormyrid fishes: Gnathonemus longibarbis

Hilgend, Gnathonemus Victoria. The East African Freshwater Fisheries Research

Organisation Annual report, Jinja, Uganda.

Ragheb E (2016) .Growth pattern and natural mortality of Elephant snout fishes (Mormyrus kannume, Mormyridae) in the Damietta branch of Nile, Egypt. Published in the Egyptian Journal of Aquatic Research.
Saha, S., and Barrow, C. J. (1981). River basin planning: theory and practice.

Scudder, T. (1980). River-basin development and local initiative in African savannah

environments. In T. Scudder, \& D. Harris (Eds.), Human ecology in savannah environments (pp. 383-405).

Tazibirwa (2016). Assessment of the influence of Bujagali dam on the spatial -temporal; fish

assemblages of the upper Victoria Nile river, Uganda. Msc. Thesis University of Natural Resources and life Sciences (BOKU), Vienna, Austria; UNESCOIHE Institute for water Education, Delft, Netherlands and Egerton University, Njoro, Kenya.

Vannote, R.L.G.W. Minshall, K. W. Cummins, J.R. Sedell, and Cushing C.E 1980. The river continuum concept. Can. J.Fish.Aquatic.Sci.37:130-137. 